\title{
ELEMEN YANG BERHUBUNGAN DENGAN KEBERHASILAN INISIASI MENYUSU DINI (IMD) DI BPM BIDAN "B" SUKASARI SERANG BARU KABUPATEN BEKASI PROVINSI JAWA BARAT TAHUN 2017
}

\author{
Anni Suciawati ${ }^{*}$ \\ 1. Fakultas Kesehatan Program Studi DIV Kebidanan, Universitas Nasional, Jakarta-Indonesia \\ *Korespondensi: Anni Suciawati | Universitas Nasional | wijaya.tzuchi@ gmail.com
}

\begin{abstract}
Abstrak
Pendahuluan: Pada faktanya tidak semua Ibu yang baru melahirkan memberikan ASI secara ekslusif kepada anak yang baru dilahirkannya, padahal hal tersebut merupakan sebuah pelaksanaan dari program Inisiasi Menyusui Dini (IMD). Kegiatan pemberian ASI tersebut biasanya dilakukan pada jam pertama kehidupan bayi yang bertujuan untuk mencegah kematian di masa awal kehidupan. Tujuan penelitian ini untuk mengetahui elemen yang berhubungan dengan keberhasilan Inisiasi Menyususi Dini (IMD).

Metode: Metode penelitian ini adalah deskripsi analitik menggunakan pendekatan cross sectional. Dalam pengumpulan data penelitian ini menggunakan metode kuisioner pada keseluruhan sample (total sampling), yakni 55 responden Adapun analisis data menggunakan univariate dan bivariate.

Hasil: menunjukan bahwa pendidikan ibu bersalin tidak berhubungan dengan keberhasilan IMD ( . Value 0,098) Pengetahuan ibu bersalin tidak berhubungan dengan keberhasilan IMD ( $p$. value 0,220). Paritas tidak berhubungan dengan keberhasilan IMD dengan $p$. value 0,508, Dukungan keluarga tidak memiliki hubungan dengan keberhasilan Inisiasi Menyusu Dini ( $p$ value 0,650,). Sedangkan, sikap bidan memiliki hubungan yang signifikan dengan keberhasilan IMD dengan ( $p$. value sebesar 0,007 ) karena nilai $p$ lebih rendah dari 0,05 .

Kesimpulan: Bahwa dari lima faktor yang diteliti diperoleh hasil 4 faktor tidak berhubungan signifikan dengan keberhasilan IMD. Dukungan keluarga merupakan faktor yang tidak berhubungan dengan keberhasilan IMD. Sikap bidan memiliki hubungan yang signifikan dengan keberhasilan IMD. Sikap bidan yang positif berperan dalam keberhasilan Inisiasi Menyusu Dini. Diharapkan Hubungan yang baik dan sikap positif dapat memudahkan bidan dalam memberikan informasi kesehatan kepada ibu bersalin.
\end{abstract}

Kata Kunci : Inisiasi menyusu dini, Pendidikan, Dukungan keluarga, Sikap, Bidan

Diterima 15 Maret 2019; Accepted 30 Juni 2019

\section{PENDAHULUAN}

Sustainable Development Goals (SDGs) atau Tujuan Pembangunan Berkelanjutan menjadikan menyusu menjadi salah satu langkah pertama bagi seorang manusia untuk mendapatkan kehidupan yang sehat dan sejahtera. Adanya faktor protektif dan nutrien yang sesuai dalam ASI menjamin status gizi bayi baik serta kesakitan dan kematian anak menurun. WHO dan UNICEF merekomendasikan kepada seluruh Ibu untuk memberikan ASI kepada bayi yang baru dilahirkannya setidaknya selama enam bulan. Hal tersebut didasari oleh penelitian epidemiologis dan bertujuan agar bayi terlindungi dari infeksi, misalnya diare, otitis media, serta infeksi saluran pernafasan Kolostrum mengandung zat kekebalan 10-17 kali lebih banyak dari susu matang (matur) (Kemenkes, 2014). Pada tahun 2003 pemerintah Indonesia mengubah rekomendasi lamanya pemberian ASI eksklusif dari 4 bulan menjadi 6 bulan (Kemenkes, 2014). Menurut penelitian IDAI, sebanyak 49,8\% Ibu melakukan pemberian ASI secara eksklusif sesuai rekomendasi WHO sedangkan penelitian lain menyatakan bahwa hampir sembilan dari sepuluh Ibu di Indonesia telah memberikan ASI kepada bayinya (Fadhila et al., 2016).

Inisiasi Menyusu Dini (IMD) adalah langkah awal tercapainya keberhasilan pemberian ASI eksklusif. Inisisasi menyusu dini adalah meletakkan bayi menempel di dada atau perut ibu segera setalah lahir, membiarkannya merayap mencari puting, kemudian menyusu sampai puas (Depkes RI, 2008) IMD sangat membantu dalam keberlangsungan pemberian ASI eksklusif dan lama menyusu, sehingga diharapkan terpenuhinya kebutuhan gizi bayi, hingga usia 2 tahun, dan mencegah anak kekurangan gizi. IMD membantu dalam menurunkan Angka Kematian Bayi (AKB) menjadi 23/1000 kelahiran hidup, meningkatkan kesehatan ibu dan mengurangi sampai tiga perempat jumlah Angka Kematian Ibu (AKI) saat hamil dan melahirkan menjadi 102/100.000 KH (Setiarini, 2013; Azriani, 2013). Pelaksanaan IMD di Indonesia masih belum sepenuhnya tepat, ada 4 kesalahan dalam pelaksanaan selama ini. Pelaksanaan 
yang kurang tepat menyebabkan keberhasilan menyusu tidak optimal, untuk mengoptimalkan menyusui dapat dilakukan dengan IMD. Supaya pelaksanaan IMD tepat dan dapat meningkatkan presentasi ibu menyusui secara eksklusif maka perlu diketahui mengenai faktor-faktor yang mempengaruhinya (Setiarini, 2013; Anggraeni et al., 2016). Hasil wawancara dengan informan disebutkan masih terdapat ibu-ibu yang tidak melakukan IMD dikarenakan alasan bayi yang baru lahir akan kedinginan, ibu merasakan kelelahan yang berlebih dan masih terdapat stereotype dimana ASI yang keluar pertama kali tidak sehat.

\section{METODE}

Desain penelitian ini menggunakan cross sectional dengan tempat penelitian di desa Sukasari Serang Baru, Bekasi, Jawa Barat. Waktu penelitian dari bulan April sampai Juni 2017 dengan Populasi yang diambil adalah semua ibu bersalin dan didapatkan sampel 55 orang. Metode pengambilan sampel menggunakan total sampling. Kriteria Inklusi yang dipenuhi untuk penelitian ini adalah ibu bersalin di Bidan "B" dan bersedia untuk diambil datanya sedangkan kriteria eksklusi yang ada adalah ibu tidak bersalin di Bidan "B" dan tidak mau untuk diambil datanya. Variabel yang digunakan meliputi variabel bebas dan terikat. Analisis statistik univariate menggunakan rumus distribusi frekuensi, standar deviasi dan prosentase sedangkan rumus analisis bivariate adalah Chi Square dengan derajat kemaknaan 5\%. Penelitian ini menggunakan program SPSS 22. Penelitian ini telah lulus komite etik dengan No: 03/EC/LPPM/UNNAS/I/18.

\section{HASIL}

Keberhasilan program Insisasi Menyusui Dini (IMD) tidak ditentukan oleh pendidikan seorang ibu, namun dukungan dari keluarga maupun sikap bidan yang menangani terhadap ibu bersalin dapat mempengaruhi keberhasilan program tersebut. Hal tersebut dapat dikuatkan dengan adanya hasil analisa univariate dan bivariate dari penelitian ini. Responden pendidikan tinggi lebih banyak presentasenya (74,55\%) dibandingkan pendidikan rendah $(25,45 \%)$ (Tabel 1). Responden yang pengetahuan baik lebih tinggi $(81,82 \%)$ dibanding pengetahuan kurang baik $(18,18 \%)$ (Tabel 2). Responden yang paritas primipara lebih rendah $(16,36)$ dibandingkan paritas multipara $(83,64 \%)$ (Tabel 3). Responden dengan dukungan keluarga lebih banyak (54,55\%) dibandingkan dengan keluarga yang kurang mendukung $(45,45 \%)$ (Tabel 4). Responden yang menyatakan sikap bidan positif lebih tinggi $(93,36 \%)$ dibandingkan sikap bidang negative $(3,64 \%)$ (Tabel 5).

\section{Analisa Univariat}

Tabel 1. Distribusi frekuensi pendidikan ibu bersalin

\begin{tabular}{ccc}
\hline Pendidikan & Frekuensi (f) & Persentase (\%) \\
\hline Tinggi & 41 & $74,55 \%$ \\
Rendah & 14 & $25,45 \%$ \\
\hline Total & 55 & $100 \%$ \\
\hline
\end{tabular}

Tabel 2. Distribusi frekuensi pengetahuan ibu postpatum

\begin{tabular}{ccc}
\hline Pengetahuan & Frekuensi (f) & Persentase (\%) \\
\hline Baik & 45 & $81,82 \%$ \\
Kurang Baik & 10 & $18,18 \%$ \\
\hline Total & 55 & $100 \%$ \\
\hline
\end{tabular}

Tabel 3. Distribusi frekuensi paritas

\begin{tabular}{ccc}
\hline Paritas & Frekuensi (f) & Persentase (\%) \\
\hline Primipara & 9 & $16,36 \%$ \\
Multipara & 46 & $83,64 \%$ \\
\hline Total & 55 & $100 \%$ \\
\hline
\end{tabular}

Tabel 4. Distribusi frekuensi dukungan keluarga

\begin{tabular}{lll} 
Dukungan Keluarga & Frekuensi (f) & Persentase (\%) \\
\hline
\end{tabular}




\begin{tabular}{ccc}
\hline Mendukung & 30 & $54,55 \%$ \\
Kurang Mendukung & 25 & $45,45 \%$ \\
\hline Total & 55 & $100 \%$ \\
\hline
\end{tabular}

Tabel 5. Distribusi frekuensi sikap bidan

\begin{tabular}{ccc}
\hline Sikap Bidan & Frekuensi (f) & Persentase (\%) \\
\hline Positif & 53 & $93,36 \%$ \\
Negatif & 2 & $3,64 \%$ \\
\hline Total & 55 & $100 \%$ \\
\hline
\end{tabular}

\section{Analisa Bivariate}

Tabel 6. Hubungan Pendidikan Ibu Bersalin dengan Keberhasilan Inisiasi Menyusu Dini

\begin{tabular}{ccccccccc}
\hline \multirow{2}{*}{ Pendidikan } & & \multicolumn{3}{c}{ IMD } & & Total & p.value \\
& & Ya & & & Tidak & \\
& F & & \% & F & \% & F & \% & \\
\hline Tinggi & 39 & 95,1 & 2 & 4,9 & 41 & 100 & $\mathbf{0 , 0 9 8}$ \\
Rendah & 11 & 78,6 & 3 & 21,4 & 14 & 100 & \\
\hline Total & $\mathbf{5 0}$ & $\mathbf{9 0 , 9}$ & $\mathbf{5}$ & $\mathbf{9 , 1}$ & $\mathbf{5 5}$ & $\mathbf{1 0 0}$ \\
\hline
\end{tabular}

Tabel 7. Hubungan Pengetahuan Ibu Bersalin dengan Keberhasilan Inisiasi Menyusu Dini

\begin{tabular}{|c|c|c|c|c|c|c|c|}
\hline \multirow{3}{*}{ Pengetahuan } & \multicolumn{4}{|c|}{ IMD } & \multicolumn{2}{|c|}{ Total } & \multirow[t]{3}{*}{ p.value } \\
\hline & \multicolumn{2}{|c|}{ Ya } & \multicolumn{2}{|c|}{ Tidak } & & & \\
\hline & $\mathbf{F}$ & $\%$ & $\mathbf{F}$ & $\%$ & $\mathbf{F}$ & $\%$ & \\
\hline Baik & 42 & 93,3 & 3 & 6,7 & 45 & 100 & 0,220 \\
\hline Kurang Baik & 8 & 80 & 2 & 20 & 10 & 100 & \\
\hline Total & 50 & 90,9 & 5 & 9,1 & 55 & 100 & \\
\hline
\end{tabular}

Tabel 8. Hubungan Paritas dengan Keberhasilan Inisiasi Menyusu Dini

\begin{tabular}{|c|c|c|c|c|c|c|c|}
\hline \multirow{3}{*}{ Paritas } & \multicolumn{4}{|c|}{ IMD } & \multicolumn{2}{|c|}{ Total } & \multirow[t]{3}{*}{ p.value } \\
\hline & \multicolumn{2}{|c|}{ Ya } & \multicolumn{2}{|c|}{ Tidak } & & & \\
\hline & $\mathbf{F}$ & $\%$ & $\mathbf{F}$ & $\%$ & $\mathbf{F}$ & $\%$ & \\
\hline Primipara & 6 & 85,7 & 1 & 14,3 & 7 & 100 & 0,508 \\
\hline Multipara & 44 & 91,7 & 4 & 8,3 & 48 & 100 & \\
\hline Total & 50 & 90,9 & 5 & 9,1 & 55 & 100 & \\
\hline
\end{tabular}

Tabel 9. Hubungan Dukungan Keluarga dengan Keberhasilan Inisiasi Menyusu Dini

\begin{tabular}{|c|c|c|c|c|c|c|c|}
\hline \multirow{3}{*}{$\begin{array}{c}\text { Dukungan } \\
\text { Keluarga }\end{array}$} & \multicolumn{4}{|c|}{ IMD } & \multirow{2}{*}{\multicolumn{2}{|c|}{ Total }} & \multirow[t]{3}{*}{ p.value } \\
\hline & \multicolumn{2}{|c|}{ Ya } & \multicolumn{2}{|c|}{ Tidak } & & & \\
\hline & $\mathbf{F}$ & $\%$ & $\mathbf{F}$ & $\%$ & $\mathbf{F}$ & $\%$ & \\
\hline Mendukung & 28 & 93,3 & 2 & 6,7 & 30 & 100 & 0,650 \\
\hline $\begin{array}{c}\text { Kurang } \\
\text { Mendukung }\end{array}$ & 22 & 88 & 3 & 12 & 25 & 100 & \\
\hline Total & 50 & 90,9 & 5 & 9,1 & 55 & 100 & \\
\hline
\end{tabular}

Tabel 10. Hubungan Sikap Bidan dengan Keberhasilan Inisiasi Menyusu Dini

\begin{tabular}{|c|c|c|c|c|c|c|c|}
\hline \multirow{3}{*}{ Sikap Bidan } & \multirow{2}{*}{\multicolumn{2}{|c|}{ Ya }} & \multirow{2}{*}{\multicolumn{2}{|c|}{ Tidak }} & \multicolumn{2}{|c|}{ Total } & \multirow{3}{*}{ p.value } \\
\hline & & & & & & & \\
\hline & $\mathbf{F}$ & $\%$ & $\mathbf{F}$ & $\%$ & $\mathbf{F}$ & $\%$ & \\
\hline Positif & 50 & 94,3 & 3 & 5,7 & 53 & 100 & $\mathbf{0 , 0 0 7}$ \\
\hline
\end{tabular}




\begin{tabular}{|c|c|c|c|c|c|c|}
\hline Negatif & 0 & 0 & 2 & 100 & 2 & 100 \\
\hline Total & 50 & 90,9 & 5 & 9,1 & 55 & 100 \\
\hline
\end{tabular}

Berdasarkan tabel 6 dapat disimpulkan bahwa responden yang berpendidikan tinggi 39 orang $(95,1 \%)$, lebih banyak dari pada responden yang berpendidikan rendah. Hasil analisa perhitungan statistik diperoleh p.value 0,098 yang lebih tinggi dari 0,05, sehingga dapat disimpulkan bahwa tidak ada hubungan yang signifikan antara pendidikan ibu bersalin dengan keberhasilan Inisiasi Menyusu Dini.

Berdasarkan tabel 7 dapat disimpulkan bahwa responden yang memiliki pengetahuan dengan kategori baik sebanyak 42 orang $(93,3 \%)$, lebih banyak dari pada responden yang memiliki pengetahuan dengan kategori kurang tahu. Hasil analisa perhitungan statistik diperoleh p.value 0,220 lebih tinggi dari 0,05 sehingga dapat disimpulkan bahwa tidak ada hubungan yang signifikan antara pengetahuan ibu bersalin dengan keberhasilan Inisiasi Menyusu Dini.

Berdasarkan tabel 8 dapat disimpulkan bahwa responden primipara yang melakukan 6 orang $(85,7 \%)$, lebih sedikit dari pada responden multipara yang melakukan. Hasil analisa perhitungan statistik diperoleh p.value 0,508 yang lebih tinggi dari 0,05, sehingga dapat disimpulkan bahwa tidak ada hubungan yang signifikan antara paritas dengan keberhasilan Inisiasi Menyusu Dini.

Berdasarkan tabel 9 dapat disimpulkan bahwa responden yang mendapat dukungan keluarga sebanyak 28 orang $(93,3 \%)$, lebih banyak dari pada responden yang tidak mendapat dukungan keluarga. Hasil analisa perhitungan statistik diperoleh p.value 0,650 yang lebih tinggi dari 0,05, sehingga dapat disimpulkan bahwa tidak ada hubungan yang signifikan antara dukungan keluarga dengan keberhasilan Inisiasi Menyusu Dini.

Berdasarkan tabel 10 dapat disimpulkan bahwa responden yang berpendapat bahwa sikap bidan positif sebanyak 50 orang $(94,3 \%)$, lebih banyak dari pada responden yang berpendapat sifat bidan negatif. Hasil analisa perhitungan statistik diperoleh p.value 0,007 yang lebih rendah dari 0,05, ada hubungan yang signifikan antara sikap bidan dengan keberhasilan Inisiasi Menyusu Dini.

\section{PEMBAHASAN}

\section{Analisa Univariat}

Manfaat menyusui dini untuk bayi adalah dapat mengurangi angka kematian bayi dan meningkatkan kesehatan, pertumbuhan serta daya taha bayi terutama di usia $0-1$ tahun. Peneliti melakukan pengambila data di daerah bekasi yang didapatkan ibu-ibu sudah melaksanakan program insiasi menyusu dini dengan baik. Pendidikan yang tinggi memberikan pengaruh terhadap pola pikir manusia dan untuk meningkatka kesadaran dan kemampuan hidup sehat bagi ibu yang menghadapi persalinan agar terwujud derajad kesehatan yang optimal. Hal ini dibuktikan dengan penelitian yang dilakukan oleh peneliti bahwasannya ibu-ibu di daerah bekasi sudah memiliki pengetahuan (74,55\%). Pengetahuan merupakan hal yang sangat penting untuk terbentuknya tindakan seseorang dengan kata lain pengetahuan mempunyai pengaruh sebagai motivasi awal bagi seseorang dalam berperilaku yang dimana peneliti mendapatkan responden memiliki pengetahuan tinggi tentang IMD. Primipara adalah tindakan yang telah pernah melahirkan lebih dari satu kali (Manuaba, 2004) dan penelitian ini lebih banyak ibu yang melahirkan secara multipara $(83,64 \%)$. Dukungan sosial sangat berperan penting dalam proses persalinan dimana dukungan keluarga seperti suami dapat memberikan rasa nyaman, semangat dan meningkatkan rasa percaya diri. Peneliti yang sudah melakukan analisis data didapatkan dukungan keluarga yang ada di daerah Bekasi dikatakan tinggi $(54,55)$. Sikap bidan yang proaktif dapat memberikan kelancara dalam proses persalinan. Hal ini dibuktikan oleh peneliti yang sudah melakukan penelitian bahwasannya bidan bersikap positif $(93,36 \%)$. Bidan memiliki peranan penting dalam pelaksanaan Inisiasi Menyusu Dini (IMD), pengetahuan dan pengalaman tenaga kesehatan sangat berpengaruh terhadap IMD (Anggraeni et al., 2016).

\section{Analisa bivariate}

\section{Hubungan antara pendidikan ibu bersalin dengan keberhasilan Inisiasi Menyusu Dini}

Pemerintah Indonesia telah mencanangkan inisiasi menyusu dini sebagai bagian dari upaya mengoptimalkan pemberian Asi secara ekslusif dan sebagai manajemen laktasi baru. Tidak selamanya pendidikan ibu mempengaruhi tingkat keberhasilan Inisiasi Menyusu Dini dan hasil penelitian yang didapatkan adalah tidak ada hubungan yang signifikan antara pendidikan ibu bersalin dengan keberhasilan 
Inisasi Menyusu Dini. Hasil penelitian ini sejalan dengan penelitian yang dilakukan di RSIA Pertiwi Makassar (Afandi et al., 2014) bahwa tidak ada hubungan yang signifikan antara tingkat pendidikan dan perilaku Inisiasi Menyusu Dini.

\section{Hubungan antara pengetahuanibu bersalin dengan keberhasilan Inisiasi Menyusu Dini}

Pengetahuan merupakan domain kognitif yang memiliki enam tingkatan, yaitu tahu, memahami, aplikasi, analisis, sintesis, dan evaluasi. Jika pengetahuan seseorang sebatas hanya pada tingkat tahu dan memahami, maka seseorang belum mengaplikasikan pengetahuannya dalam kehidupan. Teori yang disebutkan sejalan dengan fakta yang ditemukan oleh penulis dimana responden belum mengaplikasikan pengetahuannya sehingga disimpulkan tidak ada hubungan yang signifikan antara pengetahuan ibu bersalin dengan keberhasilan Inisiasi Menyusu Dini. Namun hasil penelitian ini berbeda dengan hasil penelitian di RSUD Salatiga Jawa Tengah (Khoniasari, 2015) tentang hubungan positif antara pengetahuan ibu dan pelaksanaan IMD. Hal yang menyebabkan tidak ada hubungan karena perbedaan tingkat pendidikan setiap ibu.

\section{Hubungan antara paritas dengan keberhasilan Inisiasi Menyusu Dini}

Hasil distribusi frekuensi menyatakan bahwa ibu yang ada di daerah Bekasi melahirkan lebih dari satu kali sehingga didapatkan tidak ada hubungan yang signifikan antara paritas dengan keberhasilan Inisiasi Menyusu Dini. Hasil penelitian ini tidak sejalan dengan pernyataan Roesli bahwa paritas berpengaruh terhadap proses Inisiasi Menyusu Dini (Roesli, 2012). Hal tersebut dapat terjadi karena ibu multipara mempunyai pengalaman yang lebih dibandingkan ibu primipara. Fakta yang didapat bahwa tidak ada hubungan yang signifikan antara paritas dan Inisiasi Menyusu Dini. Perbedaan hasil penelitian tersebut dapat disebabkan karena perbedaan rata-rata sifat ibu bersalin di setiap daerah dan mereka lebih menuruti perkataan tenaga medis (bidan). Jika dilihat dari hasil data banyaknya ibu dengan paritas multipara yang melaksanakan IMD menunjukkan bahwa pengalaman ibu dalam melahirkan membuat ibu lebih mudah melaksanakan IMD.

\section{Hubungan antara dukungan keluarga dengan keberhasilan Inisiasi Menyusu Dini}

Keluarga juga berfungsi sebagai sistem pendukung bagi anggotanya dan anggota keluarga memandang bahwa orang yang bersifat mendukung selalu siap memberikan bantuan jika diperlukan (Padila, 2012). Dukungan yang diberikan keluarga sangat bermanfaat untuk meningkatkan kesehatan dan adaptasi keluarga (Padila, 2012). Hasil yang berbeda didapatkan bahwa tidak ada hubungan yang signifikan antara dukungan keluarga dengan keberhasilan Inisiasi Menyusu Dini. Hasil penelitian ini sama dengan hasil penelitian Khoniasari (2015) yang menyatakan bahwa dukungan keluarga berhubungan negatif dengan pelaksanaan IMD. Kurangnya dukungan keluarga tidak terlalu berpengaruh terhadap pelaksanaan IMD karena pengetahuan ibu bersalin juga dapat mempengaruhi keberhasilan IMD.

\section{Hubungan antara sikap bidan dengan keberhasilan Inisiasi Menyusu Dini}

Peran bidan dalam memberikan dukungan pada ibu sangat penting. Bidan sebagai tempat mencurahkan kesulitan dalam menghadapi masalah seputar kesehatan. Hubungan yang baik dan sikap positif dapat memudahkan bidan dalam memberikan informasi kesehatan kepada ibu bersalin. Menurut Lawrence Green perilaku seseorang tentang kesehatan ditentukan oleh faktor pendukung yaitu adanya dukungan keuarga dan peran tenaga kesehatan (bidan). Peneliti mendapatkan kesimpulan bahwa ada hubungan yang signifikan antara sikap bidan dengan keberhasilan Inisiasi Menyusu Dini dan hal ini dikarenakan bidan selalu melakukan komunkasi pasca melahirkan. Hasil penelitian berbeda yang dilakukan di RS daerah Manado dimana proses persalinan dan dukungan suami tidak terdapat hubungan dengan pelaksanaan inisiasi menyusu dini oleh bidan di di Rumah Sakit Siloam Manado (Rompis et al., 2017). Semakin baik pengetahuan bidan tentang IMD maka keberhasilan IMD akan semakin baik dan semakin aktif bidan maka akan menunjang keberhasilan IMD dalam upaya meningkatkan keberhasilan pemberian ASI Eksklusif.

\section{KESIMPULAN}

Elemen yang berpengaruh dalam penelitian ini adalah sikap bidan terhadap keberhasilan Inisasi Menyusu Dini. Elemen pendidikan, pengetahuan, paritas dan dukungan keluarga tidak berpengaruh terhadap 
Inisiasi Menyusu Dini. Adanya beberapa elemen yang tidak berpengaruh maka perlu dilakukan penyuluhan atau sosialiasi bahwa elemen-elemen tersebut merupakan hal terpenting untuk keberhasilan proses Inisiasi Menyusu Dini dan mendukung program pemerintah tentang ASI Ekslusif.

\section{UCAPAN TERIMA KASIH}

Terimakasih kepada Redaksi Jurnal Mitra Kesehatan, STIKes Mitra Keluarga atas pembenahan dan penyempurnaan naskah yang saya ajukan. Tidak lepas juga saya ucapakan terima kasih terhadap Universitas Nasional untuk mengijinkan terbit ditempat lain.

\section{REFERENSI}

Afandi, M. I., Suhartatik and Ferial, E. W. (2014) 'Hubungan Mobilisasi Dini Dan Personal Hygiene Terhadap Percepatan Kesembuhan Luka Perineum pada Ibu Post Partum di RSIA Pertiwi Makassar', Jurnal Ilmiah Kesehatan Diagnosis, 5(3), pp. 295-301.

Aik Khoniasari (2015) Pengaruh Paritas, Pengetahuan Ibu, Dukungan Keluarga, Dan Peran tenaga Kesehatan Terhadap Pelaksanaan Inisiasi Menyusu Dini Di RSUD Salatiga, Tesis Universitas Sebelas Maret. UNIVERSITAS SEBELAS MARET. doi: 10.1017/CBO9781107415324.004.

Anggraeni, I. A., Nurdiati, D. S. and Padmawati, R. S. (2016) 'Keberhasilan ibu bekerja memberikan ASI eksklusif', Jurnal Gizi dan Dietetik Indonesia (Indonesian Journal of Nutrition and Dietetics), 3(2), pp. 69-76. doi: 10.21927/ijnd.2015.3(2).69-76.

Azriani, D. (2013) 'Keberhasilan Pemberian Asi Eksklusif', Jurnal Health Quality, 4(2), pp. 77-141.

Depkes RI (2008) 'Pesan-pesan Tentang Inisiasi Menyusu Dini (IMD) dan Air Susu Ibu (ASI) Eksklusif Untuk Tenaga Kesehatan \& Keluarga'. Indonesia.

Fadhila, S. R., Ninditya, L. and Ananta, Y. (2016) Dampak dari tidak menyusui di Indonesia, Indoensia Pediatric Society. Available at: http://www.idai.or.id/artikel/klinik/asi/d ampak-dari-tidak-menyusui-diindonesia (Accessed: 6 June 2017).

Kemenkes (2014) 'Situasi dan analisis ASI ekslusif'. Indonesia.

Manuaba, I. B. G. (2004) Penuntun Kepaniteraan Klinik Obstetri \& Ginekologi. 2nd edn. Jakarta: EGC.

Padila (2012) Buku Ajar Keperawatan Keluarga. Yogjakarta: Nuha Medika. Available at: http://library.poltekkespalembang.ac.id/ keplinggau/index.php?p=show_detail\&i d=1588.

Roesli, U. (2012) Panduan Inisiasi Menyusu Dini Plus Asi Eksklusif. Depok. Pustaka Bunda.

Rompis, O. et al., (2017) 'Faktor -Faktor Yang Berhubungan Dengan Inisiasi Menyusui Dini Di Rumah Sakit Siloam Manado', pp. 53-67. Available at: https://www.google.com/url?sa=t\&rct=j $\& \mathrm{q}=\&$ esrc=s\&source=web\&cd=1\&cad=rja\&uact=8\&ved=0ahUKEwiA_oOknoXaAhUKNY8KHWwY COMQFggrMAA\&url=http\%3A\%2F\%2Fpasca.unhas.ac.id\%2Fjurnal\%2Ffiles\%2Fab36a964c9368846 27b63c42b4ffb780.pdf\&usg= AOvVaw0WmHlrKTp0rLYejq-JXpFv.

Tatik Setiarini (2013) 'Inisiasi Menyusu Dini (IMD): Kunci Sukses Awali Keberhasilan ASI Eksklusif', Majalah Forum Ilmiah Universitas Jakarta, 17(3). Available http://www.akperkerishusada.ac.id/detai lblog-3-4.html. 